\title{
PENGARUH TERAPI REMINISCENCE TERHADAP TINGKAT STRES PADA LANSIA DI PANTI SOSIAL TRESNA WERDHA
}

\author{
Rosmin Ilham ${ }^{1}$, ,Sri A. Ibrahim ${ }^{2}$ Mitha Dewita Putri Igirisa ${ }^{3}$ \\ ${ }^{1}$ STIKES Tanawali Persada Takalar \\ ${ }^{2,3}$ Program Studi Ilmu Keperawatan UNG \\ Email : rosminilham01@gmail.com
}

\begin{abstract}
ABSTRAK
Tingkat stres pada lansia berarti pula tinggi rendahnya tekanan yang dirasakan atau dialami lansia. Salah satu pengelolaan stres pada lansia yakni dengan melakukan terapi reminiscence, yang dapat meningkatkan status kesehatan mental dengan mengingat kembali pengalaman yang menyenangkan dimasa lalu. Penelitian ini bertujuan untuk mengetahui pengaruh terapi reminiscence terhadap tingkat stres pada lansia.Penelitian ini menggunakan desain Pre experimental dengan rancanganOne grup pretest and posttest design. Populasi sebanyak 35 orang. Teknik pengambilan sampel dengan Purposive sampling. Sampel dalam penelitian ini sejumlah 15 responden lansia yang mengalami stres. Instrument yang digunakan adalah kuesioner DASS (stress scale). Analisis data menggunakan uji statistik Paired Sample $t$ Test. Hasil penelitian didapatkan bahwa terdapat perbedaan tingkat stres pada lansia sebelum dan sesudah dilakukan terapi reminiscence dengan perbedaan nilai rerata sebelum (2.67) dan sesudah (2.07), dibuktikan dengan nilai p value 0,000 ( $\alpha$ $<0,05)$. Kesimpulan penelitian ini adalah ada pengaruh terapi reminiscence terhadap tingkat stres pada lansia di Panti Sosial Tresna Werdha Ilomata Kota Gorontalo. Bagi pihak pengelola PSTW diharapkan dapat menerapkan terapi reminiscence sebagai salah satu terapi untuk mengurangi tingkat stres pada lansia.
\end{abstract}

Kata Kunci : Terapi Reminiscence, Tingkat Stres, Lansia

\section{PENDAHULUAN}

Lansia adalah seseorang yang telah memasuki usia 60 tahun keatas. Lansia merupakan kelompok umur pada manusia yang telah memasuki tahapan akhir dari fase kehidupannya.Lansia merupakan bagian dari anggota keluarga dan anggota masyarakat yang semakin bertambah jumlahnya sejalan dengan peningkatan usia harapan hidup. Secara global populasi lansia diprediksi terus mengalami peningkatan (WHO, 2013). Dari data Departement of Economic And
Social Affairs Population Division (2017) jumlah penduduk lansia di dunia pada tahun 2015 mencapai 12,3 $\%$ dari keseluruhan penduduk dunia, sedangkan jumlah penduduk lansia di Asia mencapai $11,6 \%$ dan di Indonesia mencapai $8,1 \%$ pada tahun 2015. Berdasarkan data proyeksi penduduk,jumlah penduduk lansia di Indonesia pada tahun 2017 mencapai $9,03 \%$ atau sebanyak 23,66 juta jiwa dari keseluruhan jumlah penduduk. Diprediksi jumlah penduduk lansia di Indonesia tahun $2020 \quad(27,08$ juta),tahun 2025 (33,69 juta),tahun 2030 (40,95 juta),tahun 2035 (48,19 
juta). Data ini menunjukkan jumlah penduduk lansia di negara Indonesia mengalami akan mengalami peningkatan dari tahun ketahun (Kementrian Kesehatan RI, 2017).

Jumlah populasi penduduk lansia di Provinsi Gorontalo menurut pusat data dan informasi yakni pada tahun 2015 mencapai $7.1 \%$ dengan peringkat ke14 dari seluruh provinsi di Indonesia (Kementrian Kesehatan RI, 2016). Dan pada tahun 2017 Provinsi Gorontalo menempati perin gkat ke13 denganpresentase penduduk lansia sebanyak $7.55 \%$ dari keseluruhan jumlah penduduk lansia diseluruh provinsi diIndonesia (Kementrian Kesehatan RI, 2017).

Peningkatan jumlah lansia apabila tidak mendapatkan perhatian yang serius dari berbagai pihak,tentunya akan berdampak pada meningkatnya permasalahan khususnya terkait penuaan dan kesehatan lansia. Dengan adanya perubahan-perubahan yang dialami lansia, seperti perubahan pada fisik, psikologis, spiritual, dan psikososial menyebabkan lansia mudah mengalami stres (Azizah, 2011).

Stres pada lansia dapat didefinisikan sebagai tekanan yang diakibatkan oleh stressor berupa perubahan yang menuntut adanya penyesuaian dari lansia. Tingkat stres pada lansia berarti pula tinggi rendahnya tekanan yang dirasakan atau dialami. Lansia yang tinggal di panti werdha pada umumnya mengalami kehilangan kontrol akan hidupnya secara drastis karena perasaan keterpisahan dan keterasingan. Hal tersebut dapat membuat lansia mengalami stres (Indriana,2010).
Menurut Priyoto (2014) stres dapat memberikan dampak terhadap keadaan fisiologis, psikologis, dan perilaku seseorang. Stres juga dapat berdampak terhadap kondisi emosional sehingga seseorang akan mudah gelisah atau suasana hati yang sering berubah-ubah, mudah marah, mudah tersinggung dan stres yang be rkepanjangan dapat menyebabkan seseorang menjadi cemas dan depresi bahkan akan jatuh kedalam keadaan yang lebih buruk lagi yakni bunuh diri. Untuk menghindari dampak negatif dari stres tersebut,maka diperlukan adanya suatu pengelolaan stres yang baik (Rahayuni dkk,2015).

Pengelolaan stres dapat dilakukan dengan terapi farmakologi dan terapi non farmakologi. Terapi nonfarmakologi yang dapat digunakan untuk mengurangi stresseperti terapi musik, terapi spiritual, teknik relaksasi, dan terapi kognitif perilaku, salah satunya terapi reminiscence (terapi kenangan). Reminiscence merupakan salah satu terapi yang digunakan untuk menurunkan stres dan merupakan salah satu perawatan psikologis bagi lansia yang bertujuan untuk meningkatkan status kesehatan mental mereka (Kartika dan Mardalinda, 2017).

Terapi reminiscence merupakan intervensi yang menggunakan memori untuk memelihara kesehatan mental dan meningkatkan kualitas hidup. Dalam terapi ini, terapis memfasilitasi lansia untuk mengumpulkan kembali memori masa lalu yang menyenangkan sejak masa anak, remaja, dan dewasa serta hubungan dengan keluarga, kemudian dilakukan sharing dengan orang lain. Mengenang kembali kejadian yang 
membahagiakan dimasa lalu dapat menjadi motivasi bagi lansia dalam menjalani kehidupan dan dapat menjadi suatu mekanisme koping untuk menghadapi stress (Rahayuni dkk, 2015).

Menurut Kartika dan Mardalinda (2017) dalam hasil penelitiannya bahwa terapi individu reminiscence mampu menurunkan tingkat stres pada lansia yang tinggal di rumah perawatan. Rata-rata tingkat stres responden sebelum dilakukan intervensi terapi reminiscence adalah 22.25 point dan setelah diberikan perlakuan terapi reminiscence ratarata tingkat stres responden menurun menjadi 16,60 point. Hal ini berarti terdapat penurunan yang signifikan terhadap tingkat stres lansia setelah diberikan terapireminiscence.

Studi pendahuluan yang dilakukan pada 25 Januari 2018 di Panti Sosial Tresna Werdha (PSTW) Ilomata Kota Gorontalo diperoleh jumlah lansia yang tinggal di panti sebanyak 35 orang yang terdiri dari 26 orang perempuan dan 9 orang lakilaki. Setelah dilakukan wawancara dan penilaian langsung dengan kuesioner DASS 42 (Depresion Anxiety Stress Scale) pada 10 orang lansia,diperoleh 7 orang lansia mengalami stres ringan dan 3 orang lainnya mengalami stres sedang.

Menurut hasil wawancara dengan beberapa orang lansia terkait upaya lansia dalam mengurangi stresnya adalah melaksanakan sholat, mengaji, membaca buku, membaca puisi, belajar menyanyi, menonton televisi mengurus tanaman, berusaha mengunjungi keluarga, mencari kesibukan lain dan berusaha untuk tidak mengingat lagi masalah - masalah yang ada. Berdasarkan hasil wawancara dengan pengelola PSTW, bahwaterapi reminiscence belum pernah dilakukan di PSTW ini.

Berdasarkan uraian latar belakang masalah diatas, maka peneliti tertarik untuk meneliti tentang "Pengaruh Terapi Reminiscence terhadap Tingkat Stres pada Lansia di Panti Sosial Tresna Werdha Ilomata Kota Gorontalo".

\section{METODE PENELITIAN}

Penelitian ini menggunakan desain penelitian Pre experimental design dengan rancangan One grup pretest and posttest design.Populasi sebanyak 35 orang dengan teknik pengambilan sampel menggunakan Purposive sampling. Sampel penelitian berjumlah 15 orang lansia yang mengalami stres.

\section{HASIL DAN PEMBAHASAN \\ 3.1 Hasil}

Berdasarkan hasil penelitian terhadap 15 responden adalah sebagai berikut:

Karakteristik Responden

Tabel 1 Distribusi Karakteristik Responden Berdasarkan Usia

\begin{tabular}{|c|c|c|}
\hline & $\begin{array}{c}\text { Jumlah } \\
(\mathbf{n})\end{array}$ & Presentase (\%) \\
\hline 60-74 tahun & 12 & 80.0 \\
75-90 tahun & 3 & 20.0 \\
>90 tahun & 0 & 0 \\
\hline Total & 15 & 100 \\
\hline
\end{tabular}

Sumber : Data Primer 2018

Tabel diatas menunjukkan bahwa responden yang termasuk kelompok usia 60-74 tahun sebanyak 12 responden $(80.0 \%)$, dan kelompok usia 75-90 tahun sebanyak 3 responden (20.0\%). 
Tabel 2 Distribusi Responden Berdasarkan Jenis kelamin

\begin{tabular}{|c|c|c|}
\hline $\begin{array}{c}\text { Jenis } \\
\text { kelamin }\end{array}$ & $\begin{array}{c}\text { Jumlah } \\
(\mathbf{n})\end{array}$ & $\begin{array}{c}\text { Presentase } \\
(\boldsymbol{\%})\end{array}$ \\
\hline Laki-laki & 3 & 20.0 \\
Perempuan & 12 & 80.0 \\
\hline Total & 15 & 100.0 \\
\hline
\end{tabular}

Sumber : Data Primer 2018

Tabel 2 diatas menunjukkan bahwa sebagian besar responden berjenis kelamin perempuan yakni sebanyak 12 responden (80.0\%), sedangkan responden yang berjenis kelamin laki-laki sebanyak sebanyak 3 responden $(20.0 \%)$.

Tabel 3 Distribusi Responden Berdasarkan Status Perkawinan

\begin{tabular}{|l|c|c|}
\hline $\begin{array}{l}\text { Status } \\
\text { Perkawinan }\end{array}$ & $\begin{array}{c}\text { Jumlah } \\
(\mathbf{n})\end{array}$ & $\begin{array}{c}\text { Presentase } \\
(\boldsymbol{\%})\end{array}$ \\
\hline Tidak Menikah & 1 & 6.7 \\
Menikah & 5 & 33.3 \\
Janda/Duda & 9 & 60.0 \\
\hline Total & 15 & 100 \\
\hline
\end{tabular}

Sumber : Data Primer 2018

Tabel 3 menunjukkan bahwa responden dalam penelitian ini sebagian besar sudah tidak memiliki pasangan hidup atau sudah berstatus janda/duda yakni sebanyak 9 responden $(60,0 \%)$, yang berstatus sudah menikah sebanyak 5 responden $(33.3 \%)$, serta yang berstatus tidak menikah ada sebanyak 1 responden $(6,7 \%)$.

Tabel 4 Distribusi Responden Berdasarkan Riwayat Pendidikan

\begin{tabular}{|c|c|c|}
\hline $\begin{array}{c}\text { Riwayat } \\
\text { Pendidikan }\end{array}$ & $\begin{array}{c}\text { Jumlah } \\
(\mathbf{n})\end{array}$ & $\begin{array}{c}\text { Presentase } \\
(\boldsymbol{\%})\end{array}$ \\
\hline Tidak sekolah & 1 & 6.7 \\
SD & 9 & 60.0 \\
SMP & 1 & 6.7 \\
SMA & 3 & 20.0 \\
Perguruan & 1 & 6.7 \\
Tinggi & & \\
\hline Total & 15 & 100 \\
\hline
\end{tabular}

Sumber : Data Primer 2018
Berdasarkan tabel 4 menunjukkan bahwa tingkat pendidikan responden masih tergolong rendah. Hal ini dapat dilihat dari riwayat pendidikan responden, dimana ada responden yang tidak bersekolah yakni sebanyak 1 responden (6.7\%), dengan tingkat pendidikan SD sebanyak 9 responden (60 \%), tingkat pendidikan SMP sebanyak 1 responden (6.7 \%), tingkat pendidikan SMAsebanyak 3 responden $(20.0 \%)$, tingkat pendidikan perguruan tinggi sebanyak 1 responden $(6.7 \%)$.

Tabel 5 Distribusi Responden Berdasarkan Riwayat Pekerjaan

\begin{tabular}{|c|c|c|}
\hline $\begin{array}{c}\text { Riwayat } \\
\text { Pekerjaan }\end{array}$ & $\begin{array}{c}\text { Jumlah } \\
(\mathbf{n})\end{array}$ & $\begin{array}{c}\text { Presentase } \\
(\boldsymbol{\%})\end{array}$ \\
\hline Tidak Bekerja & 5 & 33.3 \\
Wiraswasta & 8 & 53.3 \\
Karyawan & 1 & 6.7 \\
Swasta & 1 & 6.7 \\
PNS & & \\
\hline Total & 15 & 100 \\
\hline
\end{tabular}

Sumber : Data Primer 2018

Tabel 4.5 menunjukkan bahwa responden dalam penelitian ini memiliki riwayat pekerjaan yang berbeda-beda, dimana responden yang pernah bekerja sebagai wiraswasta sebanyak 8 responden (53.3\%), karyawan swasta sebanyak 1 responden $(6.7 \%)$, PNS sebanyak 1 orang (6.7\%) dan responden yang tidak bekerja sebanyak 5 responden $(33.3 \%)$.

Tabel 6 Distribusi Responden Berdasarkan Lama tinggal Gorontalo

\begin{tabular}{|c|c|c|}
\hline $\begin{array}{c}\text { Lama } \\
\text { Tinggal }\end{array}$ & $\begin{array}{c}\text { Jumlah } \\
(\mathbf{n})\end{array}$ & $\begin{array}{c}\text { Presentase } \\
(\boldsymbol{\%})\end{array}$ \\
\hline 0-5 tahun & 10 & 66.7 \\
6-10 tahun & 2 & 13.3 \\
$>10$ tahun & 3 & 20.0 \\
\hline Total & 15 & 100 \\
\hline
\end{tabular}

Sumber : Data Primer 2018 
Tabel 6 menunjukkan bahwa responden dalam penelitian ini sebagian besar adalah penghuni baru panti, karena sesuai hasil presentase yang didapat bahwa responden dengan lama waktu tinggal 0-5 tahun sebanyak 10 responden (66.7\%), 6-10 tahun sebanyak 2 responden (13.3\%), dan lebih dari 10 tahun sebanyak 3 responden $(20 \%)$ dari keseluruhan jumlah responden.

Tabel 7 Distribusi Tingkat Stres Lansia Sebelum diberikan Perlakuan (Terapi Reminiscence)

\begin{tabular}{|c|c|c|}
\hline Kategori & $\begin{array}{c}\text { Jumlah } \\
\text { (n) }\end{array}$ & $\begin{array}{c}\text { Presentase } \\
(\boldsymbol{\%})\end{array}$ \\
\hline Stres Ringan & 6 & 40.0 \\
Stres Sedang & 7 & 46.7 \\
Stres Berat & 2 & 13.3 \\
\hline Total & 15 & 100 \\
\hline
\end{tabular}

Sumber : Data Primer 2018

Tabel 7 menunjukkan tingkat stres pada lansia sebelum diberikan terapi reminiscence yakni dari 15 responden terdapat 6 responden dengan tingkat stressringan $(40.0 \%), 7$ responden de ngan tingkat stres sedang (46.7\%) dan 2 respondendengan tingkat stres berat $(13.3 \%)$.

Tabel 8. Distribusi Tingkat Stres Lansia Sesudah diberikan Perlakuan (Terapi Reminiscence)

\begin{tabular}{|c|c|c|}
\hline Kategori & $\begin{array}{c}\text { Jumlah } \\
(\mathbf{n})\end{array}$ & $\begin{array}{c}\text { Presentase } \\
(\boldsymbol{\%})\end{array}$ \\
\hline Normal & 3 & 20.0 \\
Stres Ringan & 8 & 53.3 \\
Stres Sedang & 4 & 26.7 \\
\hline Total & 15 & 100 \\
\hline
\end{tabular}

Sumber : Data Primer 2018

Tabel 8 menunjukkan tingkat stres pada lansia sesudah diberikan terapi reminiscence yakni dari 15 responden terdapat 3 responden dalam keadaan normal (20.0\%), 8 responden dengan tingkat stres ringan $(53.3 \%)$, dan 4 responden dengantingkat stres sedang $(26.7 \%)$.

Tabel 9 Analisa pengaruh terapi reminiscence terhadap tingkat stres pada lansia

\begin{tabular}{|l|l|l|l|}
\hline $\begin{array}{l}\text { Tingkat } \\
\text { Stres } \\
\text { Lansia }\end{array}$ & Mean & SD & $P$ Value \\
\hline Sebelum & 2.67 & .724 & \\
Sesudah & 2.07 & .704 & 0.000 \\
\hline
\end{tabular}

Sumber : Data Primer 2018

Tabel 9 menunjukkan perbedaan nilai rerata tingkat stres sebelum dan sesudah perlakuan (terapi reminiscence) yakni sebelum diberikan terapi rata-rata skor stres 2.67 dan sesudah diberikan terapi rata-rata skor stres 2.07. Hal ini berarti terdapat perbedaan rata-rata skor stres sebelum dan sesudah diberikan terapi reminiscence.

Hasil analisis dengan uji Paired sample t-test didapatkan bahwa nilai $P$ value sebesar $0,000 \alpha(<0,05)$ yang menunjukan bahwa ada pengaruh terapi reminiscence terhadap tingkat stres pada lansia di Panti Sosial Tresna Werdha Ilomata Kota Gorontalo.

\subsection{Pembahasan}

1. Tingkat Stres pada Lansia Sebelum Dilakukan Terapi Reminiscence

Berdasarkan hasil penelitian sebelum dilakukan terapi reminiscence didapatkan tingkat stres ringan sebanyak 6 responden $(40.0 \%)$, stres sedang sebanyak 7 responden $(46.7 \%)$, dan stres berat sebanyak 2 responden (13.3\%).

Hasil penelitian didapatkan bahwa sebelum diberikan terapi, kelompok responden dengan tingkat stres ringan $(40.0 \%)$ paling banyak 
mengalami gejala stres yakni mudah merasa kesal, mudah marah, mudah gelisah, dan sulit beristirahat. Tetapi hal tersebut kadang-kadang dirasakan oleh responden, artinya tidak sering dan hanya berlangsung dalam waktu singkat.

Untuk kelompok responden dengan tingkat stres sedang $(46.7 \%)$ mengalami gejala stres seperti mudah marah karena hal sepele, mudah tersinggung, mudah merasa gelisah, sulit untuk bersantai dan beristirahat, merasa menghabiskan banyak energi karena cemas, tidak sabaran ketika harus menunggu sesuatu, sulit tenang setelah sesuatu yang mengganggu, dan berada pada keadaan tegang (otot leher dan bahu terasa tegang). Gejala tersebut sering dirasakan responden dan berlangsung dalam waktu yang cukup lama. Sementara kelompok responden dengan tingkat stres berat $(13.3 \%)$ mengalami gejala stres yang hampir sama dengan tingkat stres sedang, namun gejala-gejala tersebut dirasakan secara terus-menerus dan dalam waktu yang lama. Dari hasil observasi, responden ini juga tampak sedih dan merasa putus asa karena sudah kehilangan pasangan hidupnya serta menderita berbagai penyakit fisik.

Hal ini sesuai dengan teori Psychology Foundation of Australia (2010) yang manyatakan bahwa stres ringan adalah stressor yang dihadapi secara teratur yang dapat berlangsung beberapa menit atau jam. Stres sedang terjadi lebih lama antara beberapa jam sampai beberapa hari. Stressor ini dapat menimbulkan gejala antara lain mudah marah, bereaksi berlebihan terhadap sesuatu, sulit beristirahat, merasa lelah karena cemas, tidak sabar ketika mengalami penundaan dan menghadapi gangguan terhadap sesuatu yang dilakukan, mudah tersinggung, gelisah, dan tidak dapat memaklumi hal apapun yang menghalangi ketika sedang mengerjakan sesuatu. Sedangkan untuk stres berat dapat terjadi dalam beberapa minggu sampai beberapa bulan yang biasanya diakibatkan oleh kesulitan finansial yang berkepanjangan dan penyakit fisik jangka panjang. Stressor ini dapat menimbulkan gejala antara lain merasa tidak kuat lagi untuk melakukan suatu kegiatan, sedih dan tertekan, putus asa, dan merasa tidak ada hal yang dapat diharapkan dimasa depan.

Dari uraian diatas terlihat bahwa masing-masing responden memiliki tingkat stres yang berbedabeda. Hal ini disebabkan karena stres pada lanjut usia dapat disebabkan oleh berbagai situasi dan kondisi sebagai akibat dari stressor berupa perubahan-perubahan baik fisik, mental, maupun sosial yang dialami lansia dan karena stres bersifat subjektif. Hal ini sesuai dengan teori yang dikemukakan Sari dkk (2015) bahwa perbedaan skor stres pada setiap responden disebabkan karena stres tersebut bersifat subjektif dan dapat dipengaruhi oleh banyak faktor.

Peneliti juga berpendapat bahwa responden dengan tingkat stres berat juga dipengaruhi oleh karakteristik responden itu sendiri, dalam hal ini adalah usia dan status perkawinan. Dimana, kedua responden ini masing-masing berusia 76 dan 90 tahun. Semakin bertambah usia seseorang maka semakin tinggi pula resiko seseorang mengalami stres. Hal ini sesuai dengan teori yang dituliskan Nasution (2011) bahwa 
umur adalah salah satu faktor penting yang menjadi penyebab stres.

Kedua responden dengan tingkat stres berat ini juga sudah tidak memiliki pasangan hidup atau berstatus janda. Kehilangan pasangan hidup menjadi salah satu faktor penyebab stres karena menimbulkan perasaan sedih yang berkepanjangan. Hal ini didukung oleh teori Sigurdardotir et al (2012) yang menyatakan bahwa pada saat ditinggalkan oleh pasangan, lansia akan mengalami rasa kesepian, kebosanan yang berpotensi menimbulkan masalah kesehatan fisik dan kesehatan jiwa.

2.Tingkat Stres pada Lansia Sesudah dilakukan terapi Reminiscence di

Panti Sosial Tresna Werdha

Ilomata Kota Gorontalo

Berdasarkan hasil penelitian ses udah terapi reminiscence, didapatkan bahwa responden dalam keadaan normal sebanyak 3 responden (20.0 $\%)$, stres ringan sebanyak 8 responden $(53.3 \%)$, dan stres sedang sebanyak 4 responden $(26.7 \%)$. Hal ini menunjukkan bahwa terjadi perubahan tingkat stres sebelum dan sesudah diberikan terapi reminiscence.

Hasil penelitian menunjukkan sesudah dilakukan terapi reminiscence, responden dengan tingkat stres berat kedua-duanya berubah menjadi stres sedang. Responden pertama mengalami penurunan skor stres dari 26 menurun menjadi 22, sedangkan responden lainnya dari skor 26 menurun menjadi 24. Perbedaan skor ini terjadi karena responden yang kedua ini masih tampak sedih dan merasa sangat kehilangan suaminya yang sudah meninggal. Pada saat pengkajian responden ini mengatakan sangat rindu dengan almarhum suaminya hingga menyebabkan ia sering merasa gelisah dan sedih.

Responden dengan tingkat stres sedang menurun menjadi 4 responden, 2 diantaranya adalah responden dengan tingkat stres berat dan 2 responden lainnya adalah responden yang hanya mengalami penurunan skor stres tetapi tidak mengalami perubahan tingkat stres sehingga masih dalam tingkat stres sedang. Hal ini dibuktikan karena pada saat pengkajian kedua responden ini mengatakan masih mudah marah karena hal sepele, mudah merasa kesal, dan mudah gelisah. Responden pertama tampak kurang bersemangat pada saat mengikuti kegiatan terapi karena dalam kondisi fisik yang kurang baik. Responden kedua juga sesekali masih memperlihatkan raut wajah yang tampak kesal karena setelah dikaji, ia mengatakan tidak menyenangi salah satu teman yang tinggal sewisma dengannya.

Responden dengan tingkat stres ringan meningkat menjadi 8 responden yang terdiri dari 3 responden yang hanya mengalami penurunan skor yang masih dalam tingkat stres ringan dan 5 responden lainnya adalah responden yang termasuk dalam tingkat stres sedang sebelumnya. Dari hasil pengkajian responden yang tidak mengalami perubahan tingkat stres tersebut mengatakan masih mudah merasa kesal, mudah gelisah dan sulit untuk beristirahat. Sedangkan untuk responden yang mengalami perubahan tingkat stres mengatakan gejala stres yang dialami sebelumnya sudah berkurang, dan pada saat terapi 
kelompok responden ini juga tampak aktif dalam kelompok baik pada saat bercerita pengalamannya maupun saat mendengarkan pengalaman teman sekelompok.

Sementara responden yang sudah dalam keadaan normal ada sebanyak 3 responden yang awalnya termasuk dalam tingkat stres ringan. Pada saat pengkajian ketiga responden ini mengatakan sudah tidak mengalami gejala-gejala stres seperti sebelumnya. Hal ini terjadi karena stres ringan hanya berlangsung beberapa menit hingga beberapa jam, jadi setelah diberikan terapi responden sudah dalam keadaan normal. Pada saat terapi ketiga responden ini juga tampak enjoy dan menikmati proses terapi.

Dengan melihat keadaan responden, peneliti menilai bahwa terapi reminiscence memang memberikan pengaruh terhadap tingkat stres pada lansia karena setelah diberikan terapi, sebagian besar lansia mengungkapkan perasaan senang dan mengatakan gejala-gejala yang dialami sebelumnya sudah berkurang. Ini membuktikan bahwa lansia sudah mampu beradaptasi dengan stres. Hal ini sejalan dengan penelitian Kartika dan Mardalinda (2017) menunjukkan pada kelompok intervensi terdapat perubahan setelah diberikan Reminiscence Therapy dari stress sedang menjadi stress ringan dimana tingkat stress sebelum intervensi 22.25 poin dan setelah dilakukan intervensi berubah menjadi 16,60 poin. Ini disebabkan karena Reminiscence Therapy fokus terhadap peristiwa-peristiwa yang menyenangkan, sehingga dengan menceritakan kenangan masa lalu dapat membantu lansia berinteraksi dan mengungkapkan perasaan kepada keluarga dan teman sehingga lansia mampu beradaptasi terhadap stres.

3. Analisa Pengaruh Terapi Reminiscence Terhadap Tingkat Stres pada Lansia di Panti Sosial Tresna Werdha Ilomata Kota Gorontalo.

Berdasarkan hasil uji statistik menggunakan uji $\mathrm{T}$ berpasangan, maka dapat dilihat dari nilai $P$ value yaitu $0,000 \alpha(<0,05)$ dimana terdapat perbedaan rerata sebelum diberi perlakuan adalah 2.67 dan sesudah diberikan perlakuan adalah 2.07, maka dapat disimpulkan bahwa terdapat perbedaan antara sebelum dan sesudah diberikan perlakuan (terapi reminiscence), yang artinya ada pengaruh terapi reminiscence terhadap tingkat stres pada lansia di Panti Sosial Tresna Werdha Ilomata Kota Gorontalo.

Berdasarkan hasil penelitian, terapi reminiscence ini dapat menurunkan tingkat stres pada lansia. Hal ini dibuktikan dengan hasil posttestatau sesudah diberi perlakuan (terapi reminiscence)yang menunjukkan bahwa terdapat 3 responden dalam keadaan normal, 8 responden dengan tingkat stres ringan, dan 4 responden lainnya dengan tingkat stres sedang.

Terapi reminiscence dapat menurunkan stres pada lansia karena terapi ini merupakan salah satu bentuk intervensi keperawatan yang mengandalkan memori, dimana terapi ini memotivasi lansia untuk mengingat kembali pengalaman keberhasilan yang pernah dialami lansia yang dapat menimbulkan perasaan bahagia, senang dan bangga. Sehingga perasaan-perasaan negatif 
dan kesedihan yang dirasakan dapat berkurang. Hal ini sejalan dengan teori Kartika dan Mardalinda (2017) yang menjelaskan bahwa Reminiscence Therapy fokus terhadap peristiwa-peristiwa yang menyenangkan pada lansia, sehingga dengan menceritakan dan mendiskusikan hal tersebut lansia menjadi senang, bangga dapat meningkatkan integritas diri dan mendapatkan penguatan positif sehingga mampu mengeliminasi peristiwa yang tidak menyenangkan.

Hal ini didukung pula oleh penelitian Putra (2014) tentang "Pengaruh Terapi Reminiscence Terhadap Depresi pada Lansia di Unit Rehabilitasi Sosial Pucang Gading Semarang" yang menyatakan bahwa dengan mengingat kembali pengalaman keberhasilan atau suka cita yang pernah dialami lansia akan menimbulkan perasaan bahagia, senang dan bangga pada saat proses terapi berlangsung. Perasaan bahagia dan bangga ini kemudian diintegrasikan dengan kemampuan dan keberhasilan lansia saat ini (usia tua). Dengan demikian lansia masih dapat memotivasi dirinya untuk menimbulkan perasaan bahagia dan bangga dengan diri sendiri, sehingga perasaan-perasaan negatif dan kesedihan yang dirasakan dapat menjadi berkurang atau bahkan hilang.

Peneliti berasumsi bahwa dengan melakukan terapi reminiscenc eatau menceritakan kenangankenangan yang menyenangkan di masa lalu, maka dengan sendirinya akan membuat lansia dapat melupakan berbagai hal yang tidak menyenangkan dalam kehidupannya saat ini. Hal tersebut dapat mengurangi emosi negatif yang dirasakan dan meningkatkan mood positif lansia. Pada saat yang sama juga akan mengalihkan pikiran lansia dari pikiran negatif menjadi pikiran positif sehingga akan merubah respon maladaptif menjadi respon adaptif.

Keberhasilan terapi reminiscence dalam menurunkan tingkat stres pada lansia juga dipengaruhi oleh cara pelaksanaan terapi. Dimana, pada penelitian ini terapi reminiscence dilakukan secara berkelompok, responden dibagi menjadi 2 kelompok dengan jumlah anggota 7-8 orang tiap kelompok. Menurut peneliti pelaksanaan terapi secara berkelompok lebih menguntungkan dibanding secara individu karena ketika dalam wadah kelompok, lansia akan lebih mudah berinteraksi dan berbagi pengalamannya dengan sesama lansia. Mereka juga akan merasa terstimulasi untuk menceritakan pengalamannya apabila sudah mendengarkan cerita dari teman kelompoknya.

Hal ini sesuai dengan teori Syarniah (2015) yang menyatakan bahwa terapi reminiscence yang diberikan secara berkelompok lebih efektif ketimbang bila diberikan secara individu. Melalui kegiatan kelompok, lansia dapat berbagi pengalaman hidup pada anggota lansia lainnya dan mendapatkan dukungan sosial dari teman sebaya.

$$
\text { Secara umum, terapi }
$$
reminiscence ini berhasil mengurangi stres yang dialami responden meskipun dengan kualitas hasil yang berbeda-beda. Dimana, dari hasil penelitian didapatkan 3 responden yang masih dalam tingkat stres ringan dan 2 responden masih dengan 
tingkat stres sedang. Responden ini hanya mengalami penurunan skor stres dan untuk tingkat stresnya masih tetap sama antara sebelum dan sesudah diberikan terapi. Perubahan skor stres yang tidak diikuti perubahan tingkat stres ini disebabkan oleh karakteristik dari masing-masing responden yang notabennya berbeda-beda.

Responden dengan tingkat stres ringan, yang tidak berubah tingkat stresnya ada sebanyak 3 responden. Dimana, responden pertamaini statusnya tidak menikah dan tidak bekerja. Jika dilihat dari status perkawinan dan riwayat pekerjaan tersebut sangat berpengaruh terhadap perubahan tingkat stresnya. Responden ini tidak menikah jadi tidak memiliki pasangan hidup. Selain itu, responden ini juga sudah tidak memiliki sanak saudara dan keluarga.

Sejalan dengan hasil penelitian Parasari (2015) tentang "Hubungan Dukungan Sosial Keluarga dengan Tingkat Depresi pada Lansia" menunjukkan hasil bahwa ada hubungan yang signifikan antara dukungan sosial keluarga dengan tingkat depresi $(\mathrm{p}=0.000, \mathrm{p}<$ 0.05).

Responden ke 3, status perkawinannya sudah tidak memiliki pasangan hidup atau berstatus janda. Status ini berpengaruh terhadap kondisi kesehatan lansia Hal ini sesuai dengan teori yang diungkapkan oleh Sigurdardotir et al (2012) yang menyatakan bahwa pada saat ditinggalkan oleh pasangan, lansia akan mengalami rasa kesepian, kebosanan yang berpotensi menimbulkan masalah kesehatan fisik dan kesehatan jiwa.
Untuk tingkat stres sedang, terdapat 2 responden yang tidak mengalami perubahan tingkat stres. Berdasarkan hasil wawancara dan observasi peneliti didapatkan bahwa hal ini terjadi karena beberapa faktor seperti kondisi kesehatan fisik yang menurundan lama tinggal di panti. Dimana, pada saat diberikan terapi reminiscence, responden pertama kondisi kesehatannya agak menurun atau dalam keadaan sakit, jadi hal ini berpengaruh terhadap perubahan tingkat stresnya ketika dilakukan penilaian kembali (posttest) setelah diberikan terapi. Hal ini sesuai dengan teori yang diungkap Fitria dalam (Aryana dan Novitasari, 2013) yang menyatakan bahwa beberapa faktor yang mempengaruhi stres pada lansia meliputi kondisi kesehatan fisik, kondisi pikologis, keluarga, dan lingkungan.

\section{KESIMPULAN}

Berdasarkan hasil penelitian yang telah dilakukan maka dapat disimpulkan

1. Tingkat stres pada lansia sebelum dilakukan terapi reminiscence di Panti Sosial Tresna Werdha Ilomata Kota Gorontalo didapatkan tingkat stres ringan sebanyak 6 responden $(40,0 \%)$, sedang sebanyak 7 responden $(46,7 \%)$ dan berat sebanyak 2 responden $(13,3 \%)$.

2. Tingkat stres pada lansia sesudah dilakukan terapi reminiscence di Panti Sosial Tresna Werdha Ilomata Kota Gorontalo didapatkan responden yang sudah dalam keadaan normal sebanyak 3 responden (20,0\%), tingkat stres ringan sebanyak 8 responden $(53,3 \%)$ dan sedang sebanyak 4 responden $(26,7 \%)$. 
3. Terdapat pengaruh terapi reminiscence terhadap tingkat stres pada lansia di Panti Sosial Tresna Werdha Ilomata Kota Gorontalo dengan menggunakan uji $\mathrm{T}$ berpasangan atau uji Paired Sample t-test didapatkan nilai $P$ value yaitu $0.000 \alpha(<0.05)$.

\section{UCAPAN TERIMA KASIH}

Peneliti mengucapkan terima kasih kepada berbagai pihak yang telah berkontribusi langsung maupun tidak langsung pada penelitian ini

\section{DAFTAR PUSTAKA}

1. Aryana,K.O dan Novitasari, D.2013.Pengaruh Teknik Relaksasi Benson Terhadap Penurunan Tingkat Stres Lansia Di Unit Rehabilitasi Sosial Wening Wardoyo Ungaran. Jurnal Keperawatan Jiwa.Vol 1.http://download.portalgaruda.o rg/article. diakses pada 06 Juni 2018

2. Azizah, L. M. 2011. Keperawatan Jiwa (Aplikasi Praktik Klinik). Graha Ilmu. Yogyakarta

3. Badan Pusat Statistik (BPS).2014.Statistik Penduduk Lanjut Usia 2014. Jakarta: Badan Pusat Statistik

4. Hertanto, K. Y. 2014. Pengaruh Terapi Relaksasi Progresif Terhadap Tingkat Stres Pada Lajut Usia Di PSTW Yogyakarta Unit Budi Luhur. Skripsi.Program Sarjana STIKES Aisyiyah Yogyakarta.ht tp://lib.unisayogya.ac.id/id/eprin $\underline{\mathrm{t} / 36}$. diakses pada 30 Januari 2018
5. Indriana, Y., I. Kristiana, A. Sonda, dan A. Intanirian. 2010. Tingkat Stres Lansia Di Panti Werdha "Pucang Gading" Semarang. Jurnal Psikologi Undip,

Vol. 8,. https://ejournal.undip.ac. id/index.php/psikologi/article/vi ew/2953/2639. diakses pada 16 Januari 2018

6. Kartika, I. R., dan Mardalinda. 2017. Pengaruh Reminiscence Therapy Terhadap Penurunan Tingkat Stres Pada Lansia. Jurnal Human Care.http://docplayer.info/48089 815-pengaruh-reminiscencetherapy-terhadap-penurunantingkat-stres-pada-lansia.html. diakses pada 19 Januari 2018

7. Kementrian Kesehatan RI. 2016. INFO DATIN : PUSAT DATA DAN INFORMASI. Situasi Lanjut Usia (LANSIA) di Indonesia. Jakarta.

8. Kementrian Kesehatan RI. 2017. Pusat Data dan Informasi. Analisis Lansia di Indonesia. Jakarta

9. Nasution, H. 2011.Gambaran Coping Stress Pada Wanita Madya Dalam Menghadapi Pramenopause.Skri psi.http://repository.usu.ac.id/bit

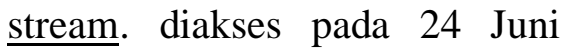
2018

10. Parasari, G A. 2015. Hubungan Dukungan Sosial Keluarga Dengan Tingkat Depresi pada Lansia di Kelurahan Sading.Jurnal Psikologi Udayana Vol 2. http://ojs.unud.ac.id. diakses pada 20 Juni 2018

11. Priyoto. $2014 . \quad$ Konsep Manajemen Stres. Nuha Medika. 
Yogyakarta

PSTW

Ilomata.2018.Profil PSTW

ILOMATA. Gorontalo:PSTW Ilomata

12. Psychology Foundation of Australia.2010.Depression

Anxiety Stress Scale.http://www. psy.unsw.edu.au/groups/dass.

diakses pada 20 Juni 2018

13. Putra, H. 2014. Pengaruh Terapi Reminiscence (Mengenang Msa Lalu Yang Menyenangkan) Terhadap Depresi pada Lansia di Unit Rehabilitasi Sosial Pucang Gading Semarang. Jurna $l$.http://happyslide.top/doc/1135 36/pengaruh-terapi-

reminiscence. diakses pada 20 Januari 2018

14. Rahayuni, N, P. Utami, dan K. Swedarma. 2015. Pengaruh Terapi Reminiscence Terhadap Stres Lansia. Jurnal Keperawatan Sriwijaya, Volume 2 - Nomor 2. https://media.neliti.com/media/p ublications/181758-ID-

pengaruh-terapi-reminiscenceterhadap-st.pdf. diakses pada 05 Oktober 2017

15. Sari, A.R, P.S Utami, dan K. Suarnata.2015.Pengaruh Senam Otak Terhadap Tingkat Stres Lansia di Panti Sosial Tresna Werdha Jara Mara Pati Singaraja.Jurnal Keperawatan $S$ riwijaya.Vol 2.https://media.neli ti.com. diakses pada 06 Juni 2018

16. Syarniah.2010.Pengaruh

Reminiscence Therapy terhadap Tingkat Stres pada Lansia di PSTW Unit Budi Luhur.Tesis. Program Magister Universitas Indonesia Jakarta.http://lib.ui.ac. $\underline{\mathrm{id} / \text { file?file }=\text { digital/137197- }}$
T\%20 Syarniah.pdf. diakses pada 17 Januari 2018

17. Syarniah, B. Keliat ., dan N. Helena. 2010.Modul Terapi Kelompok Reminiscence Untuk Klien Lansia. Fakultas Ilmu Keperawatan Universitas Indonesia.

Jakarta.http://www.academia.ed u/18501250/Modul_terapi.

diakses pada 19 Januari 2018

18. Syarniah, B. Keliat ., N. Helena., H. Susanti., \& E. Banon. 2015. Modul Terapi Keperawatan Jiwa. Workshop K eperawatan Jiwa ke-IX. http://www.academia.edu/19621 254/Modulterapi. diakses pada 20 Januari 2018

19. WHO. 2013. Mental Health And Older Adults. Retrieved from World Health Organization Web site.http://ww w.who.int/mediacentre/factsheet s/fs381/endiakses tanggal 25 Januari 201 